\title{
FLORA MALESIANA: ADDITIONS TO AND CORRECTIONS OF THE FLORA MALESIANA PRECURSORY PAPERS ON FICUS SUBGENUS PHARMACOSYCEA (2), SUBGENUS FICUS (3), SUBGENUS SYNOECIA (4), SUBGENUS SYCIDIUM (5), AND SUBGENUS SYCOMORUS (6)
}

\author{
C.C. BERG
}

The Norwegian Arboretum/Botanical Institute, University of Bergen,

N-5259 Hjellestad, Norway; Nationaal Herbarium Nederland, Universiteit Leiden branch, P.O. Box 9514, 2300 RA Leiden, The Netherlands.

\section{SUMMARY}

Corrections of and additions to previous Flora Malesiana precursors on Ficus are presented, including the publication of Ficus subsect. Sycomorus (Gasp.) C.C. Berg and subsect. Sycocarpus (Miq.) C.C. Berg.

\section{Subgenus Pharmacosycea section Oreosycea}

In the list of species of Ficus autrocaledonica-group (Berg, 2003a) the following names have to be added: F. lifouensis Corner (1970), F. otophoroides Corner (1975), and F. pteroporum Guillaumin (1967), which was overlooked by Corner (1970) but is according to Ungricht (2004) a good species. Ficus vieilardiana Bureau was incorrectly spelled.

\section{Subgenus Ficus section Eriosycea subsection Eriosycea}

Ficus hirta Vahl subsp. roxburgii (Miq.) C.C. Berg (Berg, 2003b: 537) is to be corrected into subsp. roxburghii (King) C.C. Berg.

Errata no. 2 (Berg, 2004a: 154) is to be deleted.

\section{Subgenus Synoecia}

The type of Ficus gamostyla Kochummen (1998) has been examined. The species proves to belong to the Ficus apiocarpa-group (Berg, 2003c)

It can be keyed out as follows in the key presented (p. 565-571).

Before 33:

00a. Peduncle 1-1.3 cm long; apex of lamina subacuminate acute; lamina 7-9 cm long.

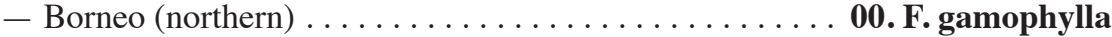

b. Peduncle $0-0.4 \mathrm{~cm}$ long; apex of lamina rounded to shortly and bluntly acuminate, or if subacute, then the lamina usually $1-5 \mathrm{~cm}$ long $\ldots \ldots \ldots \ldots 34$ 33 becomes 34,34 becomes 35 , etc. 


\section{Subgenus Sycidium}

The synonym of Ficus anastomosans (Berg, 2003d: 575) is F. tinctoria G. Forst. subsp. parasitica (Willd.) Corner var. anastomosans (Wall. ex Kurz) Corner, thus not subsp. parasitica (Miq.) Corner.

\section{Subgenus Sycomorus}

Delete from the description of the leaves for sect. Sycomorus (Berg, 2004b): or distichous and lamina asymmetric

Change the description of the leaves of sect. Hemicardia (Berg, 2004b) as follows: Leaves distichous and lamina asymmetric to symmetric on lateral branches, spirally arranged and lamina symmetric on the stem,

The subsections Sycomorus (Berg, 2004b: 158) and Sycocarpus (Berg, 2004b: 162) were not established according to the rules. It is done here:

Ficus subg. Sycomorus sect. Sycomorus subsect. Sycomorus (Gasp.) C.C. Berg, stat. nov., based on Sycomorus Gasparinni, Giorn. Bot. Ital. 2 (1844) 219.

Ficus subg. Sycomorus sect. Sycocarpus subsect. Sycocarpus (Miq.) C.C. Berg, stat. nov., based on Ficus sect. Sycocarpus Miq., Ann. Sci. Nat. Bot., Sér. 3, 1 (1844) 33.

\section{REFERENCES}

Berg, C.C. 2003a. Flora Malesiana precursor for the treatment of Moraceae 2: Ficus subg. Pharmacosycea sect. Oreosycea. Blumea 48: 289-301.

Berg, C.C. 2003b. Flora Malesiana precursor for the treatment of Moraceae 3: Ficus subg. Ficus. Blumea 48: 529-550.

Berg, C.C. 2003c. Flora Malesiana precursor for the treatment of Moraceae 4: Ficus subg. Synoecia. Blumea 48: 551-571.

Berg, C.C. 2003d. Flora Malesiana precursor for the treatment of Moraceae 5: Ficus subg. Sycidium. Blumea 48: 573-597.

Berg, C.C. 2004a. Flora Malesiana precursor for the treatment of Moraceae - Errata. Blumea 49: 154.

Berg, C.C. 2004b. Flora Malesiana precursor for the treatment of Moraceae 6: Ficus subgenus Sycomorus. Blumea 49: 155-207.

Corner, E.J.H. 1970. Ficus subg. Pharmacosycea with reference to the species of New Caledonia. Philos. Trans., Ser. B, 259: 383-433.

Corner, E.J.H. 1975. New taxa of Ficus (Moraceae). Blumea 22: 299-309.

Guillaumin, A. 1967. Résultats scientifiques de la mission franco-suisse de botanique en NouvelleCalédonie (1950-1952). Mém. Mus. Natl. Hist. Nat., Sér. B, Bot. 15: 98-102.

Kochummen, K.M. 1998. New species and varieties of Moraceae from Malaysia. Gard. Bull. Singapore 50: 197-219.

Ungricht, S. 2004. The endemic fig trees of New Caledonia. Quantitative assessment of collections for taxonomy, floristics and conservation. Thesis, University of Montpellier II. 